\title{
YOGA SASTRA: JALAN MANUNGGAL PENGARANG DALAM SASTRA KEKAWIN
}

Oleh:

\section{Ni Made Ari Dwijayanthi | Ida Bagus Putu Eka Suadnyana}

melodia.senja@gmail.com | idabaguseka09@gmail.com

Sekolah Tinggi Agama Hindu Negeri Mpu Kuturan

Singaraja

Proses Review 6-20 Maret, Dinyatakan Lolos 22 Maret

\begin{abstract}
Yoga Sastra is a path chosen by the author of kekawin to find oneness with the universe through his work. Several numbers of kekawin elaborated in this research are Kekawin Dharma Sawita, Dharma Wimala, Dharma Niskala, Dharma Sunya, Dharma Putus, Smaradahana, and also Kidung Jayendrya. The focus of this artikel is to reveal the form, function and meaning of Yoga Sastra in kekawin. The theory being used to interpret the text is Pierce's semiotic theory while Sharma's theory of rasa is utilized to analyze the depth of aesthetic experience in Kawi literary works. The result shows yoga sastra is a path of union between the author and the creator through a creative writing.
\end{abstract}

Keywords: literary yoga (yoga sastra), kekawin, unity

\section{Abstrak}

Yoga sastra dikatakan jalan yang dipilih pengarang kekawin untuk menemukan jalan kemanunggalan dengan Semesta melalui karyanya. Beberapa kekawin digunakan dalam penelitian ini yakni Kekawin Dharma Sawita, Dharma Wimala, Dharma Niskala, Dharma Sunya, Dharma Putus, Smaradahana, dan juga Kidung Jayendrya. Fokus tulisan ini untuk mengungkapkan bentuk, fungsi, dan makna yoga sastra dalam kekawin. Teori yang digunakan untuk menginterpretasi teks adalah teori semiotika dari Pierce sementara teori rasa dari Sharma digunakan untuk menganalisis kedalaman pengalaman estetik dalam karya sastra Kawi. Sehingga menghasilkan temuan berupa yoga sastra sebagai jalan manunggal pengarang dengan pencipta melalui proses kreatif karang mengarang karya sastra.

Kata Kunci: yoga sastra, kekawin, kemanunggalan 


\section{PENDAHULUAN}

Pikiran bermuara pada perkataan dan tingkah laku, setiap teks sastra Jawa Kuno (khususnya kekawin) mengisyaratkan bahwa pikiran merupakan pusat segalanya. Isi pikiran diwujudkan dengan yoga yang bermacammacam bentuknya. Yoga sastra ${ }^{1}$ merupakan jalan yang dipilih pengarang kekawin untuk menemukan jalan kemanunggalan dengan Semesta (Pencipta) melalui karyanya. Semesta dan penyair merupakan dualisme yang tidak dapat dipisahkan. Setiap musim memiliki keindahannya masing-masing. Pada manggalamanggala ${ }^{2}$ kekawin, puja seorang penyair dan keindahan alam dipadukan menjadi sebuah persembahan. Karya sastra merupakan cara pengarang untuk membebaskan diri dari belenggu kegelapan, hingga jiwa penyair terasa dibebaskan.

Apa pun memiliki tanda. Jadi hidup dan kehidupan ini penuh dengan tanda. Dilihat dari faktor yang menentukan adanya tanda, maka tanda dibedakan atas: (1) representamen, ground, tanda itu sendiri sebagai perwujudan umum: (a) qualisigns, terbentuk oleh kualitas, misalnya warna hijau; (b) sinsigns, tokens, terbentuk melalui realitas fisik, misalnya rambu lalu lintas; (c) legisigns, types terbentuk dari hukum, misalnya suara pluit wasit pertandingan sepak bola; (2) object (designatum, denotatum, refernt) diacu pada (a) ikon yaitu hubungan penanda dan petanda karena kemiripan, misalnya foto, atau jika dalam teks karya sastra berupa lukisan watak tokoh; (b) indeks, yaitu hubungan penanda dan petanda karena sebab akibat, misalnya asap-api, siang-malam; (c) simbol, yaitu hubungan penanda dan petanda yang bersifat konvensional, misalnya Widhi

1 Yoga Sastra adalah cara memuja dengan men-sthana-kan Dewa yang dipuja dan memusatkan pikiran kepada-Nya. Menulis kekawin merupakan suatu latihan yoga dan untuk memahami hal tersebut kita harus memahami ajaran yoga yang dianut oleh kawi wiku tersebut. Para kawi wiku dikenal sebagai penganut yoga yang mencari sang dewa lewat saranasarana yang menghadirkan seorang dewa atau ke dalam mana dewa turun, berhubung sarana-sarana tersebut termasuk lingkungan yang khas bagi sang kawi, maka praktikpraktik itu dengan tepat dinamakan sebagai yoga sastra (Agastia, 2010:26--27).

2 Manggala adalah bagian awal kekawin, biasanya berisikan tentang puja-puji sang penyair terhadap Bhatara yang dipujanya dan dipercayai memberikan anugerah kepada sang penyair. mengacu pada Tuhan agama Hindu; (3) interpretant, tanda-tanda yang terjadi dalam batin penerima: (a) rheme, yaitu tanda sebagai kemungkinan, semisal konsep; (b) decisigns, dicent signs, yaitu tanda sebagai fakta, semisal pernyataan deskriftif; (c) argument, yaitu tanda tampak sebagai nalar, semisal proposisi (Bandingkan dengan buku Teori, Metode, dan Teknik Penelitian Sastra (Ratna, 2004:101-104).

Manusia adalah mesin memproduksi tanda, sehingga tanda tidak akan bermakna apabila tidak ada yang menginterpretasinya. Manusia merupakan makhluk pencari makna (Bandingkan dengan Hoed, 2011:99--108). Kaitannya dengan teks kekawin adalah bahasa teks dijadikan lahan untuk memproduksi tanda. Sederhananya bahasa teks kekawin adalah tanda itu sendiri. Hasil yang diperoleh dari penelitian bukanlah struktur, melainkan proses semiosis yang memberikan makna unsur kebudayaan yang dipandang sebagai tanda.

Rasa atau pengalaman estetik diakibatkan oleh kemampuan seniman menyublimkan bhawa (emosinya) dari tataran psikologis ke tataran estetik. Bhawa adalah konsep utama yang melahirkan rasa. Dalam kreativitas imajinatif (emosi individual) ditransformasikan menjadi rasa: pengalaman estetik yang nonindividual, universal, mengatasi ruang dan waktu, serta keadaan partikular (Wiryamartana, 1990:356; Yasa, 2007:5). Sehingga, yoga sastra dalam penelitian ini dikatakan sebagai jalan penyatuan atau kemanunggalan antara pengarang dan Semesta (Pencipta) melalui karya sastra yang ditulisnya.

\section{METODE PENELITIAN}

Pembebasan jiwa penyair berupa penyerahan diri secara total kepada semesta dan penguasaNya. Jalan kemanunggalan seorang pengarang dibahas dalam penelitian ini, dengan memokuskan pada bentuk, fungsi, dan makna yoga sastra dalam kekawin. Penelitian terhadap sebuah karya sastra merupakan penelitian dalam ranah ilmu humaniora, sehingga diteliti menggunakan metode kualitatif. Selain itu metode kualitatif dapat memberikan perincian secara detail terhadap fenomena yang belum diketahui dalam objek penelitian. 


\section{ANALISIS DAN INTEPRETASI DATA}

Pierce menyatakan bahwa tanda adalah logika, hasil pemaknaan tanda dikatakannya adalah hal yang logis. Perpaduan pemikiran keduanya dapat dikatakan, bahwa semiotika adalah suatu bidang ilmu yang meneyelidiki semua bentuk komunikasi yang terjadi melalui sarana tanda-tanda dan berdasarkan pada sistem tanda. Semiotika memokuskan penelitiannya pada tanda. Teori semiotika akan membantu mengungkapkan tanda yang membentuk makna dalam kesatuan wacana kemanunggalan seorang pengarang. Sementara itu, teori rasa berperan untuk menjelaskan pengalaman estetik para pengarang dalam melakukan yoga sastra.

Pembebasan jiwa penyair berupa penyerahan diri secara total kepada semesta dan penguasaNya. Misalnya dalam penelitian ini diambil contoh dalam manggala Kekawin Smaradahana, penyerahan diri sepenuhnya penyair menggambarkan betapa tulusnya batin penyair itu. Berikut kutipannya.

Pujaniy kawi saygraheng kalayěnan mande kadirgghya yusan/ mungwin padma měkar pratiśta siniram dening

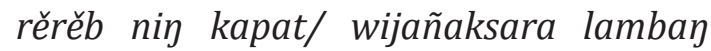

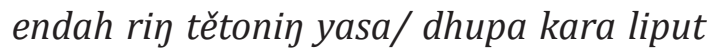

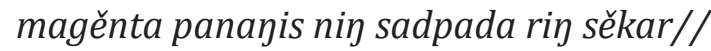
(Kekawin Smaradahana, Wirama I, Bait ke-1).

\section{Terjemahannya:}

Sembah sujudku sebagai penyair yang menginginkan keindahan agar dapat berusia panjang/ berada dan bersemayam di lubuk hati yang mekar disirami gerimis musim keempat/ beras kuningnya adalah aksara dalam kakawin yang indah yang ditebar dalam paviliun/ [menyalakan] dupa hempasan salju, [menyuarakan] genta bersuara kumbang di atas bunga// (Kekawin Smaradahana, Wirama I, Bait ke-1).

Mpu Dharmaja penggubah Kekawin Smaradahana juga menunjukkan indentitas kepengarangan yang biasa dilakukan para kawi terdahulu. Di awal, Mpu Dharmaja mengucap dirinya tidak bisa menyamai kemahakuasaan pencipta, karenanya Mpu Dharmaja memuja Bhatara dan memuji semesta. Kekuatan Bhatara dan kekuatan semesta dianggapnya kekuatan mahaabadi yang bersemanyam di tiap makluk hidup. [Pujaniy kawi saygraheng kalayěnan mayde kadirgghya yusan], terlihat jikalau sang penyair sangat hati-hati dalam kata pertama. Kata pujaning dikaitkan dengan kata selanjutnya membentuk kesatuan ide pikiran bahwasanya pemujaan tidak hanya dilakukan dengan upacara besar, tetapi penyair memuja dengan hatinya. Berikut di bawah ini merupakan daftar bulan dalam kalender Saka.

Tabel I

Daftar Bulan Menurut Penanggalan Matahari-Bulan serta Penanggalan Barat dan India (Zoetmulder, 1994:244-245)

\begin{tabular}{|l|l|l|l|}
\hline $\begin{array}{c}\text { Penanggalan } \\
\text { Barat }\end{array}$ & \multicolumn{1}{|c|}{$\begin{array}{c}\text { Penanggalan Bali } \\
\text { (Kaum Tani) }\end{array}$} & $\begin{array}{c}\text { Penanggalan } \\
\text { Matahari-Bulan }\end{array}$ & $\begin{array}{c}\text { Penanggalan } \\
\text { Musim }\end{array}$ \\
\hline Juli & Kasa & Srawana & Warsa 'hujan' \\
\hline Agustus & Karwa (Karo) & $\begin{array}{l}\text { Bhadra } \\
\text { (-pada,-wada) }\end{array}$ & Sarat 'rontok' \\
\hline September & Katelu/ Katiga & Asuji (aswayuja) & Hemanta 'dingin' \\
\hline Oktober & Kapat & Kartika & Margasirsa \\
\hline November & Kalima & Posya & \\
\hline Desember & Kanem & & \\
\hline
\end{tabular}




\begin{tabular}{|l|l|l|l|}
\hline Januari & Kapitu & Magha & \\
\hline Februari & Kawulu & Phalguna & Sisira 'sejuk' \\
\hline Maret & Kasanga & Cetra & \\
\hline April & Kadasa & Wesakha & Basanta 'semi' \\
\hline Mei & Hapit (lemah) & Jyestha & Grisma 'panas' \\
\hline Juni & Hapit (kayu) & Sadha & \\
\hline
\end{tabular}

Zoetmulder, 1994:245, menjelaskan, bahwa pada bulan Srawana musim kering mencapai

puncaknya. Pohon-pohon kehilangan kesegarannya, daun-daun menjadi merah, dan rontok sehingga dalam bulan karwa "bulan kedua" beberapa pohon menjadi gundul. Bulan Asuji juga panas, air hanya sedikit, dan jalanjalan penuh dengan debu. Pada permulaan bulan kapat awan-awan mulai tampak. Hujan pertama membangunkan pohon-pohon dari tidurnya dan mereka mulai mengeluarkan ranting-ranting baru. Pada bulan kalima biji-biji terlepas dari kelopaknya (meltik wijanya), tetapi sesudah awan-awan lewat, terik matahari makin terasa. Pada bulan kanem ladang-ladang menjadi basah, tetapi belum kuyup.

Sementara pada bulan Magha maka dengan tepat seseorang dapat melakukan mati raga dengan mandi karena hujan turun siang dan malam, sedangkan matahari dan bulan tetap bersembunyi. Selama Phalguna kandang lembu penuh dengan lumpur. Bila hujan tidak turun, para rahib meninggalkan pertapaan, mengemis susu. Akan tetapi, dalam bulan Kasanga (sembilan) langit menjadi cerah dan hujan hanya turun secara adil. Dalam Wesakha bungabunga kelihatan di mana-mana, kecuali bunga asana yang belum tampak, seolah-olah mau mengejek hujan terakhir; bila hujan itu dengan sia-sia mencari bunga asana, maka ia lenyap sambil mengucurkan air mata. Dalam bulan Jyestha hutan untuk kedua kalinya mengeluarkan bunganya, tetapi setelah hujan hilang, banyak yang gugur: gemuruh guntur terakhir menyerupai kata perpisahan seorang kekasih. Dalam bulan Asadha keindahan merana dan para kawi berkeluh menggigil kedinginan dan karena sakit panas atau demam (Zoetmulder, 1994:246).

Ketika menyebut kata kapat, di baris berikutnya dalam bait pertama Kekawin
Smaradahana, mungwin padma měkar pratiśta siniram dening rěrěb niך kapat (berada dan bersemayam di lubuk hati yang mekar disirami gerimis musim keempat), tergambar betapa lembut dan indahnya musim itu. Dikatakannya awan tersusun dari asap dupa menyamai lembutnya salju, gemuruh dalam hati menyerupai suara kumbang yang bergetar seolah menimbulkan suara genta. Kapat adalah bulan keempat dalam perhitungan tahun Saka atau sekitar bulan Oktober tahun Masehi. Kapat juga disebut dengan Karttika. Karttika merupakan bulan yang dinanti oleh para pendamba keindahan (para kawi) yang senang menikmati keindahan (aydon layö). Karena Kartika adalah bulan penuh keindahan (kalaywan), bulan yang dihiasi hujan gerimis (riris), dan suara guntur yang lemah di kejauhan (Agastia, 1999:39--43).

Ada kalanya pula penyair memberikan metafora dengan menggunakan kata sekar. Sekar tidak hanya berarti bunga biasa. Sekar dihubungkan dengan padma, yaitu bunga dengan delapan kelopak yang senantiasa menguasai segala arah. Sekar dikaitkan pula pada mati, bukanlah mati secara raga, tetapi mematikan rasa atau indra untuk mencapai kebahagiaan. Dengan demikian, jika dikaitkan dengan kata sebelumnya, sekar merupakan tujuan akhir dari penulisan kakawin ini. Timbul pertanyaan di bait ke-1 ini di baris pertama tertulis dirghgayusa (panjang umur), bukanlah sang penyair itu yang panjang umur, melainkan karyanya bisa dinikmati sepanjang masa dan oleh siapa saja (sekar, padma).

Rumusan tentang rasa yang ditulis Bharata kemudian diterjemahkan oleh Sharma (1987:95; Yasa, 2007:5--6), dirumuskan bahwa rasa dibawa bersama dengan pengalaman melalui 
hubungan antara wibhawas (keadaan atau situasi dan objek yang membangkitkan emosi), anubhawa/sthayibhawa (emosi dasar yang ada dalam diri manusia), dan wyabhicaribhawas (emosi atau keadaan mental yang bersifat sementara yang timbul sebagai penyerta dalam proses bangkitnya rasa). Sederhananya, setiap penyair menginginkan karyanya bisa dibaca, dipahami, ditafsirkan sepanjang waktu. Setiap teks mengisyaratkan keinginan penyair untuk memberikan jiwa pada karyanya sehingga karyanya dapat dinikmati pada setiap zaman. Karya yang abadi menunjukkan betapa hebatnya pencarian diri seorang kawi.

āmběk say kawi siddha śuddha kadi sāgara gumawaya těka nirmala/ icchā

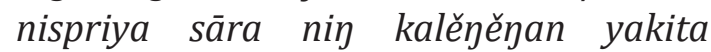
pasamudāya rị raşa/tatwajñāna wěkas nikay paramaśāstra sira ta pinakâdipandita/sākşat linga nikay sarat pinaka dippa yasa nira huwus prakāśita// (Kekawin Dharma Sunya Bait ke-1, Kekawin Dharma Niskala Bait ke-1).

\section{Terjemahannya:}

Batin sang pujangga jernih bagaikan samudra, bersinar suci tanpa noda/ hendak bebas dari saripati keindahan yang menjadi kumpulan segala rasa/ pengetahuan tertinggi merupakan puncak ajaran tertinggi. Beliau merupakan pendeta utama/ bagaikan lingga dunia, seperti lampu, karyanya memancar ke mana-mana// (Kekawin Dharma Sunya Bait ke-1, Kekawin Dharma Niskala Bait ke-1).

Batin seorang penyair diibaratkan seperti samudra yang jernih, suci, tanpa noda. Samudra sebagai kedahsyatan dan samudra sebagai kenirmalaan. Samudra digambarkan cadas, kokoh, mampu menghantam karang, namun tidak pernah dipakai dalam istilah peperangan. Samudra tidak lain pertanda gejolak dalam batin penyair yang melakukan ritual kepengarangannya. Jika diselami batin dan samudra, dianalogikan seperti ini. Pada permukaan samudra terlihat ganas, buas, garang dahsyat, tetapi pada kedalaman samudra jernih, tenang, dan damai. Itulah batin sang kawi yang bergejolak.

Pengarang kekawin umumnya memuja, melumpuhkan ego, mengembalikan diri menjadi kosong, dan siap menerima anugerah penguasa semesta. Keindahan semesta atau keadaan alam

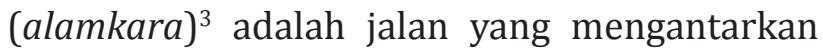
penyairmenuntaskanupacarakepengarangannya dalam bentuk yoga sastra.

Tepi laut, puncak gunung dipilih sang penyair untuk menggubah hakikat karyanya. Lautan adalah air, air merupakan sumber kehidupan, air laut menguap, menjadi awan mendung berarak menuju gunung, mendung menurunkan hujan, air hujan jatuh ke sungai, diserap tanah, menjadilah air tanah. Begitulah siklus sebenarnya, di mana pun sang kawi mengarang pastilah beliau memilih berdekatan dengan air, di tepi laut, di dasar gunung, di bawah air terjun. Hal ini dilakukan karena air adalah asal dan tujuan.

Gunung dan laut sering muncul dalam teksteks kekawin. Keduanya menggambarkan kekokohan dan kedahsyatan yang luar biasa. Gunung metafor dari ayah, sementara laut metafor dari ibu. Penyair mengawinkan gunung dan laut melalui pengembaraannya selama melakukan yoga sastra. Kekokohan gunung adalah kesejukan jika dilihat oleh mata, tetapi apabila mendakinya, kesejukan itu tidak akan dilihat lagi, tetapi dirasakan.

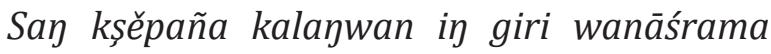
pinaka parantya niך tapa [Pencari sunyi mengagumi keindahan gunung dengan asrama di tengah hutan sebagai pengantar tapanya, Kekawin Dharma Wimala Bait ke-15, baris 1]. Setiap jalur pendakiannnya menjadi pengalaman pengembaraan si aku (atma, penyair). Begitu pula dengan laut, kedahsyatan dan

3 Alamkara/alangkara merupakan penggambaran keadaan dalam kakawin, alangkara sesungguhnya pelukisan keindahan yang dieksplorasi oleh sang penyair. Secara leksikal Alangkara berarti hiasan, hiasan bahasa, bahasa artistik. Dengan kata lain Alangkara berarti hiasan atau permainan bunyi atau kata-kata dalam syair kakawin Jawa Kuno. Alangkara merupakan bunga-bunga puisi yang dapat membangkitkan rasa estetis, lebih-lebih lagi ketika dinyanyikan dengan alunan suara yang merdu seperti biasa yang dilakukan dalam tradisi "mabebasan" di Bali. Oleh sebab itu, aspek Alangkara memegang peranan penting dalam sebuah kekawin. Aspek Alangkara dapat dibagi menjadi dua macam, yaitu Sabdalangkara adalah hiasan atau permainan kata-kata atau bunyi dan Arthalangkara merupakan hiasan atau permainan arti (Suarka, 2009:9). 
ketenangannya akan dirasakan begitu diselami ke dalam. Oleh karena itu, tidak semua hal harus dilihat oleh mata, tetapi oleh hati. Mata hati, padma hati yang ada dan senantiasa mekar, baik disirami keteduhan maupun diperciki sinar gemerlapan ketika masa pengembaraan yoga. Memang hutan, gunung, pantai, laut adalah bagian-bagian yang sangat pokok dalam kekawin. Tempat-tempat itu senantiasa dicari oleh para Kawi. Di tempat itu mereka mendapatkan kepuasan bagi kerinduannya akan keindahan. Di tempat itu mereka mendapatkan ilham. Tempat sepi yang dapat menggetarkan perasaan itu, (anětěr raras twas in kawi), adalah tempatnya mendirikan sebuah pertapaan, sebuah tempat memelihara keindahan (patapan anar tarukan niך kajěněkan amagantakěn layö). Di tempat sepi ini pula para Kawi, dinyatakan telah menyatu dengan sepi (Bandingkan dengan Agastia, 1999:20--21).

Gunung yang konon ada di pusat lingkaran mandala sebagai poros jagat raya. Mura yang ada di kaki gunung dan Wisnu (Janardhana) yang ada di pusat gunung menggelarkan yoga persatuan dan bersamadi tertuju pada Hyang Iswara yang ada di puncak. Disebutkan ada sebuah jalan membujur dari dasar sampai puncak gunung itu. Di puncaknya terdapat sebuah telaga dengan air sangat jernih memancar tidak putus-putusnya bagai permata. Di dasar telaga itu terdapat air kehidupan sebagai asal dan tujuan segala yang ada dan yang akan didapatkan bila berhasil melaksanakan yoga. Aliran kecil mengalir digerakkan oleh bayu jatuh ke dalam api sehingga tetesan berkembang menular menjadi kegelapan. Keberhasilan mengalahkan kegelapan itu disebut Jayendriya yang berarti jaya menaklukkan indra (Palguna, 1999:154-155). Jayendriya merupakan pengolahan indra seorang kawi untuk melakukan kalepasan, seperti yang dikutip dalam Kidung Jayendriya di bawah ini.

Rakryan say saksat ajöy tānuridey kawi

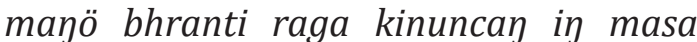
Kartika mayun hyun-hyun bhramita mayö raśmi nin asaywa lěpihin lamlam mihat ri kahayontānuksma ri sakalayön pamiśran in imāsmu riris lwir weninta mayun arsa ghriti mar maranta nuksmey rumrum niך patěr akětěr ri duk kilyan matrālon bajun

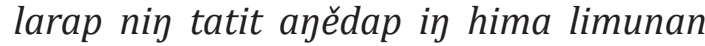
lirintāyde harsa rumta lwir panjrah niך sari sumar priyaka mèmbang panras nikiך tanu sridanta minda ri waja raśmi nì andul lwir gisi-gisyāyde ragi.

\section{Terjemahannya:}

Duhai Tuan bagaikan Dewi Keindahan yang membangkitkan cinta birahi sang kawi sebagai pecinta keindahan, dikuasai oleh kekuatan masa Kartika yang mahaindah, yang membuat hati sang kawi gelisah sehingga pergi mengembara dengan berbekal alat tulis, terpesona menyaksikan keindahanmu, menyusup dan bersatu dengan segala keindahan, bersatu padu dengan kabut. Hujan gerimis tampak bagaikan rambutmu yang membangkitkan kesenangan, membawa diri semakin dekat dengan perjalananmu menyusup ke dalam keindahan guntur yang menggelegar di arah barat, sayup-sayup bersama kilat berkelebat di kumpulan awan, lirikan matamu sungguh-sungguh membuat hati jatuh cinta, kecantikanmu bagaikan tunas bunga priyaka merambat menyayat ke dalam lubuk hati ini, gigimu bagaikan bunga srigading, keindahan bunga andul ibarat gusimu yang membuatku tergilagila.

Ada yang menarik pada kutipan Kidung Jayendriya di atas, yaitu kata sekar (bunga) kembali muncul berdampingan dengan kawi (penyair) dan kartika masa (bulan keempat Saka). Sekar (bunga) memiliki peranan dan fungsi analog dengan peranan dan fungsi Dewa Kama, terutama ketika Dewa Kama diidentikkan dengan Dewa Agni sebagai perantara yang menghubungkan manusia dengan para dewa melalui upacara korban atau yadnya. Bandingkan Manu, 1987:113 dalam Suarka, 2007:145, menyatakan, bahwa bunga sebagai perwujudan Dewa Kama di alam fana atau alam sakala menjadi perantara jiwa manusia untuk mencapai pembebasan sempurna dari ikatan keduniawian dan kemudian bersatu dengan asalnya di alam kosong yang kekal, abadi, dan damai. Bunga 
dalam hakikatnya sebagai kama atau indra dijadikan inspirasi dan sekaligus hal yang akan ditundukkan sang kawi dalam melepaskan diri dari ikatan keduniawian untuk dapat mencapai alam kalepasan atau moksa.

Wiryamartana, 1990:358 dalam Suarka, 2007:146, mengutarakan, bahwa Kidung Jayendriya yang telah dikutip pada halaman sebelumnya melukiskan alam dan manusia menjadi satu keindahan. Berhadapan dengan alam yang begitu menarik dan memesona, sang kawi sebagai pencinta keindahan (mayö) tenggelam (nuksma) dalam segala objek keindahan, ditatap hingga segala sesuatu yang lain lenyap dan terlupakan.

Keindahan yang terwujud dalam alam, kecantikan wanita, dan rasa cinta, membuat sang kawi tergila-gila (ragi) dan hanyut ke dalamnya (nuksma). Semua itu harus dikuasai dengan penuh kesadaran oleh sang kawi sehingga ia mampu mencapai alam pembebasan sempurna. Sang Kawi harus mampu menaklukkan nafsu indra atau jayendriya sebagaimana yang diindikasikan oleh judul Kidung Jayendriya tersebut. Jalan yang ditempuh sang kawi adalah dengan cara menggubah karya, dalam hal ini kidung (Sěkar Madia) mengenai bunga-bunga (sěkar) sebagai persembahan, dipersembahkan kembali pada sumber asalnya, Dewa Kama. Sejalan dengan itu, maka bunga (kembang) dan karyanya berupa kidung (tembang) dalam hakikatnya sebagai sěkar digunakan sebagai sarana melepas dan sekaligus mengantar jiwa atma untuk kembali ke sumber asalnya, Paramatma (Bandingkan dengan Suarka, 2007:146).

Menggubah karya sastra merupakan bentuk pemujaan tertinggi penyair. Ritual kepengarangan membuat semesta menjadi tempat yang paling mengagumkan. Seorang penyair mengeksplorasi imajinasinya dalam bentuk penggabungan isi pikiran, keadaan alam, dan puja terhadap Bhatara yang diinginkan dalam proses penciptaan karyanya. Bahasa dimainkan lewat rima, pilihan kata, serta permainan bunyi lalu menghasilkan gaya bahasa yang menjadikan ciri khas penyair. Sungguh mulia keinginan penyair dalam ritual kepengarangan, yaitu mewujudkan rasa bakti kepada Pencipta dengan mempersembahkan yang dimilikinya. Persembahan sederhana, yaitu kemampuan diri sendiri, melalui penggubahan sebuah karya.

Seorang penyair juga dikatakan sebagai pendeta dalam upacara karang-mengarang, bahkan penyair secara keseluruhan pada setiap gubahannya disebut-sebut sebagai para pencari kesunyian dengan menjalankan Karma Yoga. Soebadio, 1985:48 menyatakan Karma Yoga adalah bagian dari ajaran catur marga (empat jalan) memuja kekuasaan pencipta. Ajaran Karma Yoga dipahami sebagai memuja kebesaran beliau dengan cara bekerja, bekerja, dan bekerja. Mereka yang menempuh jalan ini memakai 'tubuh' atau dirinya sebagai sarana pemujaan. Pemujaan tidak hanya dilakukan dengan mencakupkan tangan, menyembahkan dengan upakara atau mengadakan upacara. Penyair melakukan pemujaan dengan pikirannya, di mana tubuh adalah upakara, kata adalah mantra, dan getaran hati adalah suara genta. Penyair menjalankan titah Sanghyang Paramawisesa sebagai pencatat dunia, sekaligus menjadi penyelamat zaman, dan pembawa pesan sebuah peradaban.

Kemanunggalan dijadikan tujuan penyatuan penyair dengan dewa keindahan. Penyatuan dewa keindahan dan penciptaan kekawin merupakan yoga yang khas bagi penyair yakni yoga keindahan dan yoga sastra. Dewa keindahan sebagai Yang Mutlak dalam alam niskala (transenden), berkat semadi sang kawi berkenan turun dan bersemayam di alam sakala-nişkala (imanen-transenden), di atas padma (mujgw in sarasija) di dalam hati atau jiwa sang kawi (twas, jñāna, hiděp, tutur). Keadaan itu membuat sang kawi dapat berhubungan dengan dewa yang tampak dalam alam sakala (imanen) dalam segala sesuatu yang indah. Dengan menyadari kesatuannya dengan dewa di dalam aneka ragam pernyataannya itu, sang kawi pun menyadari kesatuannya dengan dewa di alam niskala (transenden), yang menjadi tujuan akhir yoga (bandingkan dengan Agastia, 2010:38--39).

Penyair dikatakan pengembara, pemuja keindahan, pencari kesunyian. Batin penyair yang diibaratkan seperti samudra itu akan terus bergejolak gelisah sebelum mencari yang hilang. Pengembaraan menuju gunung (wukir), pantai, hutan, dan sungai dijalankan sambil berlaku 
tapa. Penyatuan antara semesta dan penyair kemudian menjelma dalam bentuk karya. Selalu ada kerinduan untuk melakukan penyatuan. Betapa uniknya penyatuan ini, sungguh mepesona dengan bebasnya jiwa pada saat melakukan ritual kepengarangan. Penyair menggabungkan pengalaman estetik dan religiusnya ke dalam karya.

Pengalaman-pengalaman pengembaraan penyair tidak selalu tenggelam ke dalam keindahan alam, sesuatu yang sensual, dan fenomena belaka, tetapi tenggelam dalam Yang Mutlak, di mana penyair mengatasi segala nafsu dan godaan. Dalam arti penyair sudah menjalani tahap-tahap dhyana dan dharana, lalu sampai pada samadhi. Hal itu diterapkan dalam hubungan kekawin dengan pembaca dan pendengarnya sehingga dapat dikatakan bahwa kekawin menyebabkan para pembaca atau pendengarnya akan merasakan pengalaman penyair, yaitu tenggelam ke dalam alam fenomenal, tembus sampai ke hakikatnya, bertemu dengan Sang Keindahan sendiri (bandingkan dengan Agastia, 2010:41--42). Inilah yang penulis pahami tentang penyair kekawin, yaitu sebagai pembawa pesan peradaban.

Kekuatan pemujaan penyair merupakan kerinduan untuk selalu melakukan bakti dengan cara menuangkannya ke dalam karya. Bakti adalah cinta yang selalu mendorong keinginan penyair untuk membuktikannya. Kerinduan menjadi penggerak dalam setiap karya yang digubahnya. Besarnya kerinduan terlihat dan tersebar di seluruh teks.

Ritual kepengarangan pada hakikatnya adalah aktivitas bersastra bagi penyair yang berpusat kepada ajaran yoga. Yoga merupakan proses menyatukan diri dengan Paramasiwa. Dengan demikian dalam setiap karya selalu tertuang bukan hanya nilai keindahan, melainkan juga nilai religius. Nilai-nilai ini tidak akan habis dikupas dari waktu-waktu karena karya sastra (kekawin) yang digubah merupakan tujuan akhir penyair, yaitu mencapai pembebasan jiwa (kalepasan).

Kenikmatan dan keindahan tertinggi adalah kumpulan segala rasa. Baris pertama bait ke-3 dari Kekawin Dharma Putus menegaskan

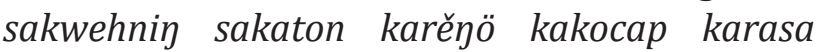

kāyěn-ajěn pwa tan hana, [semua yang dilihat, didengar, diucapkan, dirasakan, dipikirkan adalah sesuatu yang tidak ada]. Penyair (aku atau atma, pencari sunyi, pemuja keindahan) dikatakan tenang apabila seseorang mulai mengabaikan segala yang didengar, dilihat, dan dirasakannya. Hal itu terjadi karena apa pun yang didengar, dilihat, dan dirasakan adalah sesuatu yang tidak ada (Paramasiwa raja diraja semesta). Keheningan, diperoleh apabila telah melakukan jalan yoga, mematikan semua rasa lalu menggubah karya.

Para pencari kesunyian sejatinya adalah mereka yang memiliki kesetiaan tanpa perlu diragukan. Kesetiaan tidak menuntut untuk berkorban, tetapi menuntun ke arah pembebasan jiwa. Pencarian akan berakhir ketika telah menemukan sesuatu yang hilang. Mencari yang tidak ditemukan, menemukan yang tidak dicari. Hilang, lepas, menyatu seiring dengan meningkatnya bakti kepada-Nya Yang Mahatinggi.

Tan trěsna ri sukmaña tan hana sinaクsayanira ri patingalin sarat, [dia tidak cinta pada dirinya, tidak ada keraguan untuk meninggalkan dunia], (Kekawin Dharma PutusBaitke-5). Sesungguhnya kerinduan akan penyatuan membuat aku (atma, penyair) melakukan persembahan, yaitu dirinya sendiri. Tidak sayang kepada diri sendiri merupakan ungkapan untuk menyatakan betapa besarnya keinginan untuk bersatu. Pengembaraan melahirkan pengalaman, lalu kemudian menumbuhkan rasa ingin mengorbankan diri.

Pengorbanan dilandasi kesetiaan tertinggi dari dalam diri. Para penyair kekawin dalam mencurahkan kreativitasnya, selalu berusaha membangkitkan keinginan, rasa terpesona, dan spiritualitas dalam karya-karyanya dengan menghubungkan cerita imajiner tentang masa lalu, tetapi nyata (Bandingkan dengan Creese, 2012:269). Yoga sastra dijalani dengan menciptakan karya sastra. Menulis merupakan jalan pengendalian diri yang paling tinggi. Oleh karena itu, baik menggubah, mencipta, maupun menulis kekawin merupakan cara yang dipilih untuk mencapai kebebasan diri.

Palguna, 1999:193, menegaskan, bahwa perjalanan terakhir seorang penyair adalah perjalanan menghilangkan semua yang telah 
dicapai dalam perjalanan (pengembaraan) sebelumnya. Melepaskan jñāna atau sakti berarti menghancurkan semua wujud kenyataan yang diketahui. Apabila berhasil menghancurkan semua itu, seorang penyair akan menjadi mukti, yaitu merasakan jiwanmukta atau moksa.

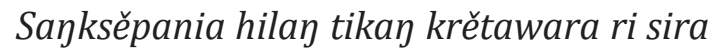
wuwus atingal ing kriya/ ya denin ya tatan hanaguru kasisya risira natimuddha ñirguna/ ngka teygwan katěmu $\eta$ rasa ta

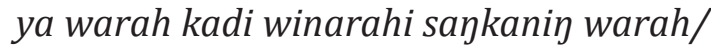

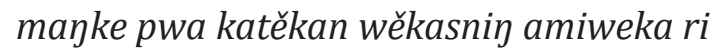
hilayanikay tutur hiděp// (Kekawin Dharma Putus, Wirama I, Bait Ke-4).

\section{Terjemahannya:}

Pendeknya, tiada anugerah dari beliau yang telah meninggalkan upacara religi/ makanya adalah tidak ada guru tidak ada murid, bagi beliau tidak ada kebodohan, tidak ada kekurangan/ itulah tempat pertemuan perasaan yang disadari bagaikan diberi tahu oleh sabda Ilahi/ kini hingga di kemudian hari manakala memperlakukan dengan hati-hati hilangnya kesadaran batin// (Kekawin Dharma Putus, Wirama I, Bait ke-4).

Sesungguhnya sesuatu yang dicari ke luar akan ditemukan dan hilang di dalam diri. Tidak ada yang lebih bodoh atau lebih pandai, tidak ada guru pun tidak ada murid. Semua sama, lahir dari kekosongan berakhir dengan kehampaan. Tubuh aku (atma, penyair) adalah kumpulan rasa yang dipertemukan oleh keinginan penyaatuan. Kerinduan pemujaan sama dengan keperihan yang indah. Bukankah, semua bermula dari dalam diri, maka tetaplah kembali ke dalam diri.

Diri merupakan kuil pemujaan, "alam olah tapa-brata itu konsentrasi batin merupakan salah satu praktik yang paling penting sehingga lambat laun "diri pribadi" atau Atman makin diutarakan. Dalam lingkungan kehidupan pribadi sang Atman-lah menjadi pusat yang memancarkan segala daya kekuatan, sama seperti Brahman yang menjadi pusat semesta" (Zoetmulder, 1991:58). Paramasiwa yang dituju ada pada pusat di dalam tubuh, pada hulu hati sehingga diri menjadi tempat bernaung semesta.
Cukup pujalah semua yang ada dalam diri karena di setiap tempat tubuh manusia adalah tempat para dewa. "Segala sesuatu (dalam tubuhmu) merupakan hidup yang keramat (Sang Hyang Hurip), merupakan Ciptaan Tertinggi (Wisesa-Karya), tubuhmu: dalam tangan, dalam kaki, kulit, daging, otot, tulang, pembuluh utama, buah pelir, jantung, empedu, pangkal tenggorokan" (Soebadio, 1985:111). Oleh karena itu, setiap titik pada tubuh adalah aksara yang hidup dan selalu bergerak ke segala penjuru menghidupkan sudut-sudut pikiran.

Bait ke-4 dari Kekawin Dharma Putus yang telah dikutip di awal subbab di atas mewakili kesederhanaan jalan kemanunggalan Kesederhanaan yang dimaksudkan bukanlah tanpa usaha, melainkan tanpa upacara. Justru ritualyang terpenting adalah ritual perkumpulan rasa (ngka teygwan katěmu $\eta$ rasa ta ya warah kadi winarahi saykanin warah/ itulah tempat pertemuan perasaan yang disadari bagaikan diberi tahu oleh sabda Ilahi). Tubuh adalah tempat pertemuan rasa, setiap rasa berkumpul di hulu hati. Pusat yang dikatakan menjadi bagian tengah-tengah tubuh, baik secara vertikal maupun horizontal ialah hulu hati.

Soebadio, 1985:45--48, menjelaskan aksaraaksara yang dimiliki di setiap titik pada tubuh akan hidup dan berputar di dalam hulu hati. Setiap aksara yang terdiri atas sepuluh aksara (SA, BA, TA, A, I, NA, MA, SI, WA, YA disebut dasaksara), kemudian menjadi lima aksara (SA, BA, TA, A, I disebut pancaksara), lalu menjadi tiga aksara (ANG, UNG, MANG disebut tryaksara), dan terakhir menjadi (OM disebut ekaksara). Ekaksara menyuarakan OM dengan sebutan ongkara. Penghuni hulu hati adalah ongkara ngadeg dan ongkara nyungsang. Keduanya perwujudan lingga-yoni yang mewakili karakter maskulin dan feminis dalam diri. Jika ongkara ini diputar, maka timbullah getaran yang menciptakan kehangatan, kenikmatan, dan kebahagiaan yang luar biasa.

Analog tubuh dengan semesta beserta para dewa yang bersemayam dipaparkan dalam Kidung Ajikembang (bait 1-10). Dikatakan bahwa sinar suci Sanghyang Widhi dalam wujud sembilan dewa, menghuni kesembilan penjuru alam semesta dan organ vital dalam tubuh manusia dalam rangka memberikan kekuatan 
dan perlindungan demi kesempurnaan hidup manusia. Kesembilan dewa penguasa tubuh dan semesta disebut dengan dewata nawa sanga, terdiri atas Dewa Iswara, Dewa Maheswara, Dewa Brahma, Dewa Rudra, Dewa Mahadewa, Dewa Sangkara, Dewa Wisnu, Dewa Sambu, dan Dewa Siwa (Suarka, 2007:157).

Suarka, 2007:157 menegaskan, bahwa di alam semesta, Dewa Iswara berada di alam timur. Di dalam tubuh (manusia), Dewa Iswara bersemayam di jantung bertugas memberikan keselamatan dan perlindungan, kekayaan, serta menumbuhkan rasa bakti kepada Tuhan. Dewa Maheswara berada di alam tenggara. Di dalam tubuh manusia, Dewa Maheswara bersemayam di paru-paru, memberikan kepandaian sehingga manusia mahir dalam kehidupan. Dewa Brahma berada di alam selatan, bersemayam di hati, memberikan kekuatan dan perlindungan sehingga manusia menjadi sempurna, panjang umur, dan mampu menguasai pengetahuan suci. Dewa Rudra berada di alam barat daya, bersemayam di usus, memberikan kesadaran akan kebenaran, mendidik manusia berperilaku baik, dan menjadi teladan di muka bumi.

Dewa Mahadewa berada di alam barat. Di dalam tubuh, Dewa Mahadewa bersemayam di ginjal, memberikan kekuatan dan perlindungan kepada manusia serta menumbuhkan sifat dan sikap keberanian pada diri manusia. Dewa Sangkara bersemayam di alam barat laut, dalam tubuh bersemayam di limpa, memberikan kekuatan dan perlindungan kepada manusia dalam mengendalikan diri dan memiliki kesetiaan. Dewa Wisnu menguasai alam utara, bersemayam di empedu, memberikan kekuatan dan perlindungan sehingga manusia memiliki keteguhan hati, sopan dalam bertingkah laku, bijaksana, dan rupawan. Dewa Sambu berada di timur laut, bersemayam di katup jantung, memberikan kekuatan dan perlindungan serta menumbuhkan rasa kedamaian dan cinta kasih pada diri manusia. Dewa Siwa berada di alam tengah, bersemayam dalam tumpukan hati, memberikan kekuatan dan perlindungan serta menumbuhkan kewibawaan, tingkah laku luhur, kesetiaan, kejujuran, dan kegemaran untuk melakukan semadi pada diri manusia (Suarka, 2007:157).

\section{SIMPULAN}

Yoga sastra adalah menyatukan aku dan semesta diyakini sebagai hukum jagat raya yang kekal oleh waktu. Barang siapa yang memahami hakikat dirinya sebagai individu akan selalu merasa nyaman dan lega dalam keadaan apa pun. Mereka yang memahami hakikat dirinya akan siap menyatu dengan-Nya kapan saja. Bukan lagi bergantung pada kehendak waktu, melainkan waktu hanya akan menjadi media yang menyaksikan. Sementara ruang menyediakan dirinya untuk mengabdi pada yang sudah menemukan hakikat dirinya karena Dia (semesta, Brahman) itulah kenyataan tertinggi yang tidak diselami oleh akal budi dan panca indra. 


\section{DAFTAR PUSTAKA}

Agastia, Ida Bagus Gede. 1999. Di Kaki Pulau Bali. Denpasar: Yayasan Dharma Sastra. 2010. Yoga Sastra. Denpasar: Yayasan Dharma Sastra.

Creese, Helen. 2012. Perempuan dalam Dunia Kakawin; Perkawinan dan Seksualitas di Istana Indic Jawa dan Bali. Denpasar: Pustaka Larasan.

Palguna, IBM Dharma. 1999. Dharma Sunya Memuja dan Meneliti Siwa. Denpasar: Yayasan Dharma Sastra.

Ratna, Nyoman Kutha. 2007. Teori, Metode, dan Teknik Penelitian Sastra dari Strukturalisme hingga Poststrukturalisme Perspektif Wacana Sastra. Yogyakarta: Pustaka Pelajar.

Soebadio, Haryati. 1985. Jnanassiddhanta. Jakarta: Djambatan.

Suarka, I Nyoman. 2007. Kidung Tantri Pisacarana. Denpasar: Pustaka Larasan.

Yasa, I Wayan Suka. 2007. Teori Rasa: Memahami Taksu, Ekspresi, dan Metodenya. Denpasar: Widya Dharma.

Zoetmulder, P.J. 1994. Kalangwan Sastra Jawa Kuno Selayang Pandang (cetakan ketiga). Penerjemah Dick Hartoko SJ. Jakarta: Djambatan. 